\title{
The Role of Polymorphisms in Host Immune Genes in Determining the Severity of Respiratory Illness Caused by Pandemic H1N1 Influenza
}

\author{
Y. Keynan a-c, e S. Malik ${ }^{d}$ K.R. Fowke ${ }^{a, b, e}$ \\ Departments of a Medical Microbiology, ${ }^{\mathrm{b}}$ Community Health Sciences, and ${ }^{\mathrm{C}}$ Internal Medicine, University of \\ Manitoba, Winnipeg, Man., and d Laboratory for Foodborne Zoonosis, Office of Biotechnology, Genomics \& \\ Population Health, Public Health Agency of Canada, Ottawa, Ont., Canada; ${ }^{e}$ Department of Medical Microbiology, \\ University of Nairobi, Nairobi, Kenya
}

\author{
Key Words \\ CCR5 $\cdot$ H1N1 influenza $\cdot$ Host genetics Immunoglobulin \\ deficiency $\cdot \mathrm{KIR}$
}

\begin{abstract}
Following the influenza epidemics, it has become clear that severity of illness is not uniform. Comorbidities and immunocompromise account for only a fraction of severe cases and do not explain the differential severity among the otherwise healthy during pandemics. During the 2009 H1N1 pandemic, a focus has been placed on better understanding of the determinants and pathogenesis of severe influenza infections. Much of the current literature has focused on viral genetics and its impact on host immunity as well as novel risk factors for severe infection (particularly within the H1N1 pandemic). The improved understanding of the cellular mechanisms and pathways involved in the pathogenesis of severe disease along with technological advances have allowed a more systematic approach to the exploration of the host genetic determinants of susceptibility and severe respiratory illness. By better defining the role of genetic variability in the immune responses to influenza, and identifying key polymorphisms that either protect against severe manifestation or those that impair the host immune response, it is
\end{abstract}

possible to envision better methods to identify at-risk populations and new targets for therapeutic interventions and vaccines. This review will summarize the accumulated literature examining the immunogenetic factors associated with propensity for the development of severe pandemic H1N1 (pH1N1) manifestations. We will focus on novel and key insights gained through study of ethnic populations that appeared more vulnerable to severe disease during the 2009 H1N1 pandemic.

Copyright $\odot 2013$ S. Karger AG, Basel

\section{Introduction}

Influenza pandemics are caused by the emergence of strains that are sufficiently different from prior circulating strains, where pre-existing immunity is not able to provide complete protection. The pandemics of the 20th century and the pandemic of 2009 resulted in high disease burden accompanied by significant morbidity and mortality. The disease severity during the 2009 pandemic varied from very mild to fatal disease, and during the pandemics, it was noticeable that traditional risk factors such as extremes of age and immunocompromise failed to account for the variation. In order to predict which popula-

Dr. Yoav Keynan

Room 507 Basic Medical Science, University of Manitoba

745 Bannatyne Avenue

Winnipeg, MB R3E 0J9 (Canada)

E-Mail keynany@yahoo.com 
tions may be at highest risk of infection and to direct delivery of effective therapeutic interventions and vaccines to those at risk, a thorough understanding of both viral and host contribution to pathogenesis is required. In the recent $2009 \mathrm{H} 1 \mathrm{~N} 1$ pandemic, the availability of advanced technology resulted in a plethora of studies that offered a glance into the impact of viral evolution and mutation on viral pathogenesis. In addition, based on human and animals model studies of the host immune response to infection and the realization of contributors to severe disease, the host immune response and the genetics that underlie it were examined. Genetic variation in immune-related genes has now been shown to account for disparate susceptibility of numerous infectious agents and may be contributing to the variation observed in $\mathrm{pH} 1 \mathrm{~N} 1$ susceptibility and disease severity. Identification of host genetic polymorphisms contributing to altered susceptibility or disease severity has the potential for impact by allowing identification of high-risk populations, where prophylactic interventions may be a higher priority. Elucidation of host proteins important in virus-host interactions and causing collateral damage may lead to new targets for therapeutic interventions or vaccine development [1].

The 2009 appearance of a swine origin reassortant virus initially in Mexico with subsequent spread throughout North America and globally led to the first pandemic of the 21st century. Past pandemics were marked by the fact that certain individuals or populations appeared to be more susceptible to severe disease; however, the ability to conduct studies in order to understand the immune mechanisms that underlay the increased propensity for complications was limited. The $2009 \mathrm{H} 1 \mathrm{~N} 1$ pandemic was accompanied by improved preparedness and surveillance, thereby facilitating better estimation of disease severity and methods to examine the immune mechanisms behind complicated disease [2-11]. This surveillance allowed for the identification of several novel risk factors among various populations but with a limited understanding of the genetic variation that may contribute to those risk factors.

\section{Risk Factors Associated with Severity of the 2009 Pandemic H1N1 Infection}

Extremes of age and immune deficiencies are known contributors to disease severity in the context of seasonal influenza. In contrast, the $1918 \mathrm{H} 1 \mathrm{~N} 1$, as well as the recent 2009 pandemics, were notable for the comparatively high rates of morbidity among healthy, young adults not typically observed with seasonal influenza [11]. During the recent pandemic, several studies of confirmed pH1N1 cases in Canada and the US reported the median age of severe infections to be 23-27 years old $[8,10]$. In Canada, only $30-48 \%$ of infections occurred in individuals with comorbidities such as: diabetes, heart disease, lung diseases, obesity, and immunosuppression [10, 12-14]. In addition, pregnancy appeared as an important risk factor; among hospital admissions, pregnancy accounted for roughly $30 \%$ of female cases aged $20-39$ years old $[9,12$, 15].

Ethnicity emerged as risk factor of $\mathrm{pH} 1 \mathrm{~N} 1$ susceptibility, as it was identified in several populations in North America and Australasia. The increased proportion of Aboriginal individuals presenting with severe $\mathrm{pH} 1 \mathrm{~N} 1$ infection was previously seen in the $1918 \mathrm{H} 1 \mathrm{~N} 1$ pandemic, during which mortality in Aboriginal communities in North America (3-9\%) was significantly higher than among non-Aboriginal communities [16, 17]. In the 2009 pandemic, Kumar et al. [12] also reported $25.6 \%$ of the individuals admitted to intensive care units (ICUs) in Canada belonged to Aboriginal ethnicities; this is an overrepresentation compared to the $4.4 \%$ rate of self-reported Aboriginal ethnicity according to the 2001 census (Statistics Canada). Similarly, pH1N1 mortality rates among American Indian/Alaska Natives were 4 times higher than persons in all other ethnic populations combined in the US [18]. Similarly, native communities in Australasia were more severely affected. Pacific Islanders accounted for $2.5 \%$ of the Australian population but made up $9.7 \%$ of patients admitted to Australian ICUs with confirmed pH1N1. Maori individuals represent $13.6 \%$ of the New Zealand population but accounted for $25 \%$ of ICU admissions in the ANZIC study (Australian and New Zealand Intensive Care Study) [19]. These studies point to the presence of vulnerable populations, but did not delineate the underlying causes of this apparent predisposition to severe disease. A combination of several risk factors, acting in concert, is needed to explain the high rates of complications. Socio-economic factors leading to inability to access care, delays in seeking care, higher rates of poverty, malnutrition, and greater numbers of household members may all play an important role. Underlying mechanisms behind some of the risk factors converge to a degree of immune system impairment, raising the possibility that the ability to mount a cross-reactive immune response to a newly encountered influenza strain, with emphasis on the role of cell mediated immunity, is decreased in some of the previously described groups (pregnancy is a good example).
Keynan/Malik/Fowke 
Table 1. Suggested genetic polymorphisms associated with H1N1 susceptibility and severity

\begin{tabular}{|c|c|c|c|}
\hline Gene & Polymorphism & Functional significance & Ref. \\
\hline CCR5 & $\mathrm{CCR} 5 \Delta 32$ & Increased allele frequency among Canadian H1N1 ICU cases & 31 \\
\hline KIR & 2DL2/L3 & Increased allele frequency among Canadian H1N1 ICU cases & 25 \\
\hline IFTIM 3 & $\begin{array}{l}\text { rs } 12252 \text { altered splice } \\
\text { acceptor }\end{array}$ & Increased among hospitalized H1N1from England and Scotland & 37 \\
\hline \multirow{2}{*}{$\begin{array}{l}\text { FcyRIIa, } \\
\text { IGHG } 2\end{array}$} & $\mathrm{IGHG} 2{ }^{*} \mathrm{n} /{ }^{*}-\mathrm{n}$ & IgG2 subclass deficiency reported in association with severe H1N1 & \multirow[t]{2}{*}{34} \\
\hline & Fc $\gamma$ RIIa-R131H & $\begin{array}{l}\text { Polymorphisms linked to IgG2 deficiency were not confirmed in } \\
\text { H1N1 patients }\end{array}$ & \\
\hline
\end{tabular}

\section{Immunogenetic Risk Factors Associated with Severity of the 2009 Pandemic H1N1 Infection}

The antibody response directed largely at the surface glycoproteins provides short-lived protection, limited to the specific influenza strain. It is, however, ineffective in the context of novel strains with altered surface antigens, as is seen with new pandemic strains. It is therefore thought that innate and cell mediated responses are crucial in provision of heterosubtypic cross-protection. Genetic polymorphisms that lead to impaired innate signaling or diminished CD8 responses may lead to impaired ability to abrogate an infection caused by novel influenza strains and may, therefore, be associated with adverse outcomes. During the 2009 H1N1 pandemic, several immunogenetic determinants of severe disease were identified.

\section{Killer Immmunoglobulin-Like Receptors}

Natural killer (NK) cells are important components of the innate response to influenza. They are capable of producing effector antiviral functions as well as playing a role in shaping the adaptive responses. Their activity is determined by a balance between activating and inhibitory receptors [20-23]. One of the classes of inhibitory receptors, the Killer-cell immunoglobulin-like receptors form a large family of receptors that recognize HLA Class I ligands and induce an inhibitory response, thought to be important in preventing damage to healthy tissue. In a recent study, reduced NK cell frequencies were observed among patients with severe responses to $\mathrm{H} 1 \mathrm{~N} 1 / 09$ infections, when compared to mild cases and healthy controls [24]. This study was limited to a small case-series, and it is difficult to draw conclusions. The role of NK in determination of severity is strengthened by a study of a First Nations community that was severely af-

Host Immune Genes and Severity of

Pandemic H1N1 Influenza fected during the first wave of the $2009 \mathrm{H} 1 \mathrm{~N} 1$ pandemic revealed low degree of 3DL1/S1 diversity, relative to Caucasian populations and ICU non-Aboriginal patients. Four allotypes accounted for the majority of Aboriginal subjects, and the 2DL2/L3 ligand-positive pairs were common among patients requiring ICU admission, in comparison to the individuals from the same community that did not suffer from severe influenza. The authors conclude that the 2DL2/L3-ligand interactions may be involved in determining the greater risk for severe disease [25]. Taken the limited evidence together, it appears that NK interaction with T cells may be of importance in setting the stage for severe manifestations of H1N1 influenza.

\section{CCR5 $\Delta 32$ Allele}

The CCR5 protein is a chemokine receptor expressed on $\mathrm{T}$ cells, macrophages and dendritic cells, and it is thought to be important in mediating leukocyte chemotaxis in response to chemokine. The interaction of the receptor with its ligands results in the homing of many immune cells to the mucosal surfaces-site of viral invasion. CCR 5 receptor deficiency as a result of $\Delta 32$ allele has been known to protect against HIV acquisition. More recent research has resulted in broadening of the understanding of the roles played by CCR 5 , when the $\Delta 32$ allele was found to be associated with an increased risk of symptomatic and fatal West Nile virus infection, a severe adverse reaction to the live yellow fever virus vaccine, as well as with severe tickborne encephalitis symptoms [26-30]. The disparities in disease severity during the $2009 \mathrm{H} 1 \mathrm{~N} 1$ pandemic led our group to study CCR5 genotype among patients with respiratory failure requiring ICU admission. Among individuals with confirmed severe $\mathrm{pH} 1 \mathrm{~N} 1$ infection, the CCR $5 \Delta 32$ allele was found in $55.6 \%$, giving 
a Caucasian allele frequency of $27.8 \%$ [31] (table 1). This observed frequency is approximately 2.5 times higher than reported for local North American Caucasian populations and may be associated with a plausible biological mechanism; however, the sample size of this study was small and the observation is yet to be repeated in additional cohorts.

\section{Immunoglobulin G2 Subclass Deficiency}

IgG2a and IgG2b are able to bind to Fc receptors with high affinity and are thought to be important in the protection against influenza infection. An Australian study identified an index case of severe influenza in a pregnant woman with IgG2 subclass deficiency and subsequently measured total IgG and IgG subclasses in all patients with $\mathrm{pH} 1 \mathrm{~N} 1$ infection requiring ICU care. A significant proportion of the participants were pregnant. Severe cases had a low level of IgG2 and these low levels were correlated with disease severity using multivariate analysis, compared to less severe controls and asymptomatic pregnant women presenting to antenatal clinic. Repeated measurement of IgG2 3 month later among 15 of the surviving IgG2-deficient patients showed that 11 of them remained IgG2 deficient despite the return of albumin to baseline values [32]. A study from China that compared IgG2 levels among Asian patients with respiratory failure due to severe pandemic influenza to mild cases did not find cases of selective IgG2 deficiency. They did find lower levels of IgG2 among the severe cases (despite normal levels of the other IgG subclasses) [33]. They suggested that the presence of cytokine dysregulation among severe $\mathrm{pH} 1 \mathrm{~N} 1$ infections is a result of exuberant Th1 response and a suppressed Th2 response and may explain the low IgG2. Thus, the role of genetic IgG2 subclass deficiency remains to be proven. An additional study from Mexico, consisted of case-control genotyping of $91 \mathrm{pa}-$ tients with confirmed severe pneumonia from $\mathrm{A} / \mathrm{H} 1 \mathrm{~N} 1$ infection as well as 98 asymptomatic household contacts with presumed exposure. They found an association of 4 single nucleotide polymorphisms (SNPs) with severe disease. One of the SNP's identified was the low-affinity IIA receptor, Fc fragment of IgG, along with a polymorphism in complement component 1. Taken together, these 2 suggest an involvement of immune complexes and complement activation in determining the risk for severe pneumonia due to $\mathrm{A} / \mathrm{H} 1 \mathrm{~N} 1$ influenza infection [34].

\section{Additional Candidate Polymorphisms Contributing to Severe Pandemic H1N1 Influenza}

Genetic polymorphisms associated with $\mathrm{pH} 1 \mathrm{~N} 1$ susceptibility and disease severity identified to date are limited and much of the data is derived from small cohorts. An improved understanding of the sequence of immune responses to influenza can be used to guide a more focused approach to identify specific pathways that may be differentially activated by individuals with severe disease. Based on available data, we can identify several immune pathways and their genetic variants that warrant further investigation.

The CD8+ T cell response is a strong predictor of vaccine-induced protection among the elderly and individuals with comorbidities that result in a decreased ability to mount a protective antibody response. The targets of the cell mediated immune responses are found within the relatively conserved viral proteins. In contrast to antibody IgG responses aimed at surface glycoproteins, CD8+ T cell responses are capable of providing some cross-reaction against new influenza strains and have attracted significant attention with the hope of generating a more broadly protective vaccine $[35,36]$. HLA alleles are the most variable human genes, and on a population level, variable proportions of HLA class I alleles may correlate to qualitatively and quantitatively distinct CD8+ T cell responses. Multiple lines of evidence point to differences of breadth and magnitude of responses among individuals baring distinct HLA class I alleles. Boon et al. [37] demonstrated that the frequency of CTL responses specific for the HLA-B8-restricted epitope $\mathrm{NP}_{380-388}$ was lower in HLA-B27-positive donors than in HLA-B27negative donors and that the HLA-A1-restricted epitope $\mathrm{NP}_{44-52}$ responses were higher in HLA-A1-, -A2-, -B8-, and -B35-positive donors than in other donors [37]. Despite the fact that the potential impact of CD8+ T cells on attenuating the course of influenza is well documented, the role of HLA class I alleles in determining pH1N1 influenza severity remains unexplored. Severe cases during pandemic H1N1 are associated with exuberant inflammation and cytokine release, accounting for some of the tissue damage. Interferon-induced transmembrane protein 3 (IFITM3) is thought to play a role in restricting influenza virus replication. The critical role is supported by the observation that mice lacking IFITM3 develop fulminant viral pneumonia after challenge with a low-pathogenicity influenza. A recent study of 53 hospitalized A/ H1N1infected patients from England and Scotland documented a synonymous SNP, thought to alter the first
12

Public Health Genomics 2013;16:9-16 DOI: $10.1159 / 000345937$
Keynan/Malik/Fowke 
splice acceptor site and to be associated with the IFITM3 splice variant, to be enriched among hospitalized individuals [38].

\section{Vitamin D Immune Modulating Effects}

Several lines of evidence, derived from epidemiological $[39,40]$, in vivo [41], in vitro [42-44], and randomized controlled trials [45], implicate a role of vitamin D in influenza infection. The underlying molecular mechanism is not fully understood but vitamin D may play a role in disease pathogenesis by eliciting rapid-acting antiviral peptides $[46,47]$ and/or dampening excessive virus-induced inflammation [48] (cytokine storm), which may otherwise lead to severe infection. Surprisingly, little has been reported on the association between genetic variants in the vitamin $\mathrm{D}$ biosynthetic/immunomodulatory pathway and severe influenza, knowledge that may explain the disparity between mild and severe outcomes of infection. Moreover, Larcombe et al. [49] reported higher frequency of SNPs in the vitamin D receptor leading to low expression of the receptor among individuals of First Nation ethnicities in Canada. It is possible that the presence of altered vitamin $\mathrm{D}$ receptor signaling may contribute to the vulnerability to severe disease observed during H1N1 influenza pandemics. Additional investigation of this hypothesis is warranted to provide a better understanding to how vitamin $\mathrm{D}$ impacts the natural history of influenza infection and, further, can influence public health recommendations for vitamin $\mathrm{D}$ supplementation with a view to mitigate severe influenza infection.

Additional factors are summarized in a review of 72 manuscripts published by Hornby et al. [50]. From this extensive review, it is clear that the susceptibility to severe pandemic influenza in humans is polygenic, and it is determined by pathogen characteristics and the interaction between those and multiple host factors that also include prior infection history, comorbidities as well as environmental factors. Pandemic H1N1 presents a unique opportunity to study genetic susceptibility to severe influenza in different populations and in a manner that is less confounded by infection history and pathogen variability. The absence of single genes that are able to explain differences in susceptibility and the association with genes representing a myriad of pathogenetic mechanism suggests a hypothesis-free genome-wide approach may be valuable in order to gain additional insights into the predisposition to severe disease.

Host Immune Genes and Severity of Pandemic H1N1 Influenza

\section{Gene Expression Studies - An Exploratory Tool for the Study of Genetic Susceptibility to H1N1 Infection}

The development of high throughput methods to study the genomics of response to pathogens has been utilized to study disease severity caused by the 2009 H1N1 pandemic influenza. Bermejo-Martin et al. [51] studied 19 critically ill patients from Spain, with documented primary $\mathrm{pH} 1 \mathrm{~N} 1$ influenza pneumonia. They applied gene expression, cytokine measurement and pathway analysis aiming to interrogate host immune responses associated with severe disease. They identified impaired expression of a number of MHC class II and MHC class I genes, T cell receptor-associated genes, granzyme B associated signaling, genes related to B cell maturation as well as a cluster of genes thought to be involved in antigen presentation in the most severe group of patients. The group with severe illness also showed higher expression of genes involved in IL-6 and IL-10 pathways, along with high serum levels of the same cytokines. The authors found a pronounced elevation of proinflammatory cytokines, along with high levels of immunosuppressive cytokines in serum among the individuals with poorest outcomes. They concluded that severe disease is associated with an impaired transition from innate to adaptive immunity in response to the $\mathrm{pH} 1 \mathrm{~N} 1 \mathrm{vi}$ rus resulting in delayed viral clearance. This study did not examine the role of genetic polymorphisms in the apparent immune perturbations [50,51]. One mechanism that may lead to the excessive release of pro-inflammatory cytokines may be mediated through the recognition of viral molecular patterns by the 3 families of pattern recognition receptors (RIG-I like helicase family, the Toll-like receptor family, and the nucleotide binding domain and leucine-rich-repeat-containing family). These are thought to be a key in early response to viral pathogens, and the activation of ensuing cascades helps to shape the adaptive responses [53, 54]. Allen et al. [52] demonstrated that NLRX1 may play an inhibitory role on antiviral signaling pathways. Using NLRX1 knockout mice, they illustrated upregulation of IFN $\beta$, STAT, OAS1 and IL- 6 with resulting increased mortality. The balance of activation and inhibition of anti-inflammatory cascades may be altered due to polymorphisms in genes involved in the pattern recognition pathways; however, studies in humans are lacking.

It is conceivable that such polymorphisms may contribute to differential susceptibility to pandemic $\mathrm{H} 1 \mathrm{~N} 1$ influenza infection. Using the data from these studies can

Public Health Genomics 2013;16:9-16 
guide more detailed targeted pathway examination comparing individuals with severe disease to those with asymptomatic or mild infections.

\section{Conclusions}

Several lines of evidence suggest that different populations have disparate degrees of susceptibility to $\mathrm{pH} 1 \mathrm{~N} 1$ and that host variation in key genes associated with the appropriate immune response could play an important role in determining the outcome of infection. The development of newer tools, including massively parallel sequencing platforms capable of simultaneously measuring gene expression levels as well as genetic polymorphisms will undoubtedly result in the discovery of some genetic predictors of morbidity and mortality caused by $\mathrm{pH} 1 \mathrm{~N} 1$. The addition of measurement of cytokine levels based on pathways identified as a result of the genomics approach will help to validate the role that signaling through the pathways discovered plays. Combination of the sequencing approach with a functional measure is thus necessary in order to illustrate a mechanism behind predisposition to severe disease caused by H1N1 influenza and may result in identification of potential targets for therapeutic interventions. Several challenges to conducting such studies include: the recruitment of appropriate controls, ideally individuals with asymptomatic or mild infections, obtaining ethical permission to carry out genetic polymorphism studies, the need for large numbers of wellcharacterized clinical specimens with relevant clinical data, and limited access to a sufficient number of samples from severe and fatal cases at a single institution. Despite the aforementioned hindrances, such research with multiple sites collaborating may provide insights into the determinants of susceptibility, and this understanding of the extreme phenotype of disease may eventually result in preventive and treatment interventions directed at the most at-risk populations.

\section{References}

1 Horby P, Sudoyo H, Viprakasit V, Fox A, Thai PQ, Yu H, Davila S, Hibberd M, Dunstan SJ, Monteerarat Y, Farrar JJ, Marzuki S, Hien NT: What is the evidence of a role for host genetics in susceptibility to influenza A/ H5N1? Epidemiol Infect 2010;138:15501558.

2 Presanis AM, De Angelis D; New York City Swine Flu Investigation Team, Hagy A, Reed C, Riley S, Cooper BS, Finelli L, Biedrzycki P, Lipsitch M: The severity of pandemic H1N1 influenza in the United States, from April to July 2009: a Bayesian analysis. PLoS Med 2009;6:e1000207.

-3 Presanis AM, Lipsitch M, De Angelis D; Swine Flu Investigation Team, New York City Department of Health and Mental Hygiene, Hagy A, Reed C, Riley S, Cooper B, Biedrzycki $\mathrm{P}$, Finelli L, BJ: The severity of pandemic H1N1 influenza in the United States, AprilJuly 2009. PLoS Curr 2009; 1:RRN1042.

-4 Archer B, Cohen C, Naidoo D, Thomas J, Makunga C, Blumberg L, Venter M, Timothy G, Puren A, McAnerney J, Cengimbo A, Schoub B: Interim report on pandemic H1N1 influenza virus infections in South Africa, April to October 2009: epidemiology and factors associated with fatal cases. Euro Surveill 2009; 14:19369.

5 Donaldson LJ, Rutter PD, Ellis BM, Greaves FE, Mytton OT, Pebody RG, Yardley IE: Mortality from pandemic A/H1N1 2009 influenza in England: public health surveillance study. BMJ 2009;339:b5213.
6 European Centre for Disease Prevention and Control (ECDC): Announced cumulative number of confirmed fatal cases of 2009 pandemic influenza A(H1N1). 2010, 2011.

-7 Echevarría-Zuno S, Mejía-Aranguré JM, Mar-Obeso AJ, Grajales-Muñiz C, RoblesPérez E, González-León M, Ortega-Alvarez MC, Gonzalez-Bonilla C, Rascón-Pacheco RA, Borja-Aburto VH: Infection and death from influenza A H1N1 virus in Mexico: a retrospective analysis. Lancet 2009;374:20722079.

-8 Louie JK, Acosta M, Winter K, Jean C, Gavali S, Schechter R, Vugia D, Harriman K, Matyas B, Glaser CA, Samuel MC, Rosenberg J, Talarico J, Hatch D; California Pandemic (H1N1) Working Group: Factors associated with death or hospitalization due to pandemic 2009 influenza $\mathrm{A}(\mathrm{H} 1 \mathrm{~N} 1)$ infection in California. JAMA 2009;302:1896-1902.

-9 Vaillant L, La Ruche G, Tarantola A, Barboza P; epidemic intelligence team at InVS: Epidemiology of fatal cases associated with pandemic H1N1 influenza 2009. Euro Surveill 2009; 14:19309.

10 Campbell A, Rodin R, Kropp R, Mao Y, Hong Z, Vachon J, Spika J, Pelletier L: Risk of severe outcomes among patients admitted to hospital with pandemic (H1N1) influenza. CMAJ 2010;182:349-355.

11 Girard MP, Tam JS, Assossou OM, Kieny MP: The 2009 A (H1N1) influenza virus pandemic: a review. Vaccine 2010;28:4895-4902.
12 Kumar A, Zarychanski R, Pinto R, Cook DJ, Marshall J, Lacroix J, Stelfox T, Bagshaw S, Choong K, Lamontagne F, Turgeon AF, Lapinsky S, Ahern SP, Smith O, Siddiqui F, Jouvet P, Khwaja K, McIntyre L, Menon K, Hutchison J, Hornstein D, Joffe A, Lauzier F, Singh J, Karachi T, Wiebe K, Olafson K, Ramsey C, Sharma S, Dodek P, Meade M, Hall R, Fowler RA; Canadian Critical Care Trials Group H1N1 Collaborative: Critically ill patients with 2009 influenza $\mathrm{A}(\mathrm{H} 1 \mathrm{~N} 1)$ infection in Canada. JAMA 2009;302:1872-1879.

13 Zarychanski R, Stuart TL, Kumar A, Doucette S, Elliott L, Kettner J, Plummer F: Correlates of severe disease in patients with 2009 pandemic influenza (H1N1) virus infection. CMAJ 2010;182:257-264

14 Hanslik T, Boelle PY, Flahault A: Preliminary estimation of risk factors for admission to intensive care units and for death in patients infected with $\mathrm{A}(\mathrm{H} 1 \mathrm{~N} 1) 2009$ influenza virus, France, 2009-2010. PLoS Curr 2010; 2:RRN1150.

15 Creanga AA, Johnson TF, Graitcer SB, Hartman LK, Al-Samarrai T, Schwarz AG, Chu SY, Sackoff JE, Jamieson DJ, Fine AD, Shapiro-Mendoza CK, Jones LE, Uyeki TM, Balter S, Bish CL, Finelli L, Honein MA: Severity of 2009 pandemic influenza A (H1N1) virus infection in pregnant women. Obstet Gynecol 2010;115:717-726.

16 Graham-Cumming G. Health of the original Canadians, 1867-1967. Med Serv J Can 1967; 23:115-166. 
17 Johnson NP, Mueller J: Updating the accounts: global mortality of the 1918-1920 'Spanish' influenza pandemic. Bull Hist Med 2002;76:105-115.

18 Centers for Disease Control and Prevention (CDC): Deaths related to 2009 pandemic influenza A (H1N1) among American Indian/ Alaska Natives - 12 states, 2009. MMWR Morb Mortal Wkly Rep 2009;58:1341-1344.

- 19 ANZIC Influenza Investigators, Webb SA, Pettilä V, Seppelt I, Bellomo R, Bailey M, Cooper DJ, Cretikos M, Davies AR, Finfer S, Harrigan PW, Hart GK, Howe $\mathrm{B}$, Iredell JR, McArthur C, Mitchell I, Morrison S, Nichol AD, Paterson DL, Peake S, Richards B, Stephens D, Turner A, Yung M: Critical care services and $2009 \mathrm{H} 1 \mathrm{~N} 1$ influenza in Australia and New Zealand. N Engl J Med 2009;361: 1925-1934.

20 Fauci AS, Mavilio D, Kottilil S: NK cells in HIV infection: paradigm for protection or targets for ambush. Nat Rev Immunol 2005;5: 835-843.

-21 Vivier E, Tomasello E, Baratin M, Walzer T, Ugolini S: Functions of natural killer cells. Nat Immunol 2008;9:503-510.

-22 Vivier E, Raulet DH, Moretta A, Caligiuri MA, Zitvogel L, Lanier LL, Yokoyama WM, Ugolini S: Innate or adaptive immunity? The example of natural killer cells. Science 2011; 331:44-49.

23 Höglund P, Brodin P: Current perspectives of natural killer cell education by MHC class I molecules. Nat Rev Immunol 2010;10:724734.

-24 Denney L, Aitken C, Li CK, Wilson-Davies E, Kok WL, Clelland C, Rooney K, Young D, Dong T, McMichael AJ, Carman WF, Ho LP: Reduction of natural killer but not effector CD8 T lymphocytes in three consecutive cases of severe/lethal H1N1/09 influenza A virus infection. PLoS One 2010;5:1-9.

-25 La D, Czarnecki C, El-Gabalawy H, Kumar A, Meyers AF, Bastien N, Simonsen JN, Plummer FA, Luo M: Enrichment of variations in KIR3DL1/S1 and KIR2DL2/L3 among H1N1/09 ICU patients: an exploratory study. PLoS One 2011;6:e29200.

26 Glass WG, McDermott DH, Lim JK, Lekhong S, Yu SF, Frank WA, Pape J, Cheshier RC, Murphy PM: CCR5 deficiency increases risk of symptomatic West Nile virus infection. J Exp Med 2006;203:35-40.

-27 Lim JK, Louie CY, Glaser C, Jean C, Johnson B, Johnson H, McDermott DH, Murphy PM: Genetic deficiency of chemokine receptor CCR5 is a strong risk factor for symptomatic West Nile virus infection: a meta-analysis of 4 cohorts in the US epidemic. J Infect Dis 2008; 197:262-265.

-28 Glass WG, Lim JK, Cholera R, Pletnev AG, Gao JL, Murphy PM: Chemokine receptor CCR5 promotes leukocyte trafficking to the brain and survival in West Nile virus infection. J Exp Med 2005;202:1087-1098.
29 Pulendran B, Miller J, Querec TD, Akondy R, Moseley N, Laur O, Glidewell J, Monson N, Zhu T, Zhu H, Staprans S, Lee D, Brinton MA, Perelygin AA, Vellozzi C, Brachman P Jr, Lalor S, Teuwen D, Eidex RB, Cetron M, Priddy F, del Rio C, Altman J, Ahmed R: Case of yellow fever vaccine-associated viscerotropic disease with prolonged viremia, robust adaptive immune responses, and polymorphisms in CCR5 and RANTES genes. J Infect Dis 2008;198:500-507.

30 Kindberg E, Mickiene A, Ax C, Akerlind B, Vene S, Lindquist L, et al. A deletion in the chemokine receptor 5 (CCR5) gene is associated with tickborne encephalitis. J Infect Dis 2008;197:266-269.

31 Keynan Y, Juno J, Meyers A, Ball TB, Kumar A, Rubinstein E, Fowke KR: Chemokine receptor $5 \Delta 32$ allele in patients with severe pandemic (H1N1) 2009. Emerg Infect Dis 2010; 16:1621-1622.

32 Gordon CL, Johnson PD, Permezel M, Holmes NE, Gutteridge G, McDonald CF, Eisen DP, Stewardson AJ, Edington J, Charles PG, Crinis N, Black MJ, Torresi J, Grayson ML: Association between severe pandemic 2009 influenza A (H1N1) virus infection and immunoglobulin $\mathrm{G}(2)$ subclass deficiency. Clin Infect Dis 2010;50: 672-678.

33 Chan JF, To KK, Tse H, Lau CC, Li IW, Hung IF, Chan KH, Cheng VC, Lai TS, Woo PC, Chan EY, Yuen KY: The lower serum immunoglobulin G2 level in severe cases than in mild cases of pandemic H1N1 2009 influenza is associated with cytokine dysregulation. Clin Vaccine Immunol 2011;18:305-310.

-34 Zúñiga J, Buendía-Roldán I, Zhao Y, Jiménez L, Torres D, Romo J, Ramírez G, Cruz A, Vargas-Alarcon G, Sheu CC, Chen F, Su L, Tager AM, Pardo A, Selman M, Christiani DC: Genetic variants associated with severe pneumonia in $\mathrm{A} / \mathrm{H} 1 \mathrm{~N} 1$ influenza infection. Eur Respir J 2012;39:604-610.

35 Powers DC, Manning MC, Hanscome PJ, Pietrobon PJ: Cytotoxic T lymphocyte responses to a liposome-adjuvanted influenza A virus vaccine in the elderly. J Infect Dis 1995;172: 1103-1107.

36 McElhaney JE, Xie D, Hager WD, Barry MB, Wang Y, Kleppinger A, Ewen C, Kane KP, Bleackley RC: T cell responses are better correlates of vaccine protection in the elderly. J Immunol 2006;176:6333-6339.

37 Boon AC, de Mutsert G, Graus YM, Fouchier RA, Sintnicolaas K, Osterhaus AD, Rimmelzwaan GF: The magnitude and specificity of influenza A virus-specific cytotoxic T-lymphocyte responses in humans is related to HLA-A and -B phenotype. J Virol 2002;76: 582-590.
8 Everitt AR, Clare S, Pertel T, John SP, Wash RS, Smith SE, Chin CR, Feeley EM, Sims JS, Adams DJ, Wise HM, Kane L, Goulding D, Digard P, Anttila V, Baillie JK, Walsh TS, Hume DA, Palotie A, Xue Y, Colonna V, Tyler-Smith C, Dunning J, Gordon SB; GenISIS Investigators; MOSAIC Investigators, Smyth RL, Openshaw PJ, Dougan G, Brass AL, Kellam P: IFITM3 restricts the morbidity and mortality associated with influenza. Nature 2012;484:519-523.

39 Cannell JJ, Vieth R, Umhau JC, Holick MF, Grant WB, Madronich S, Garland CF, Giovannucci E: Epidemic influenza and vitamin D. Epidemiol Infect 2006;134:1129-1140.

-40 Viboud C, Alonso WJ, Simonsen L: Influenza in tropical regions. PLoS Med 2006;3:e89.

41 Young GA Jr, Underdahl NR, Carpenter LE: Vitamin D intake and susceptibility of mice to experimental swine influenza virus infection. Proc Soc Exp Biol Med 1949;72:695-697.

42 Liu PT, Schenk M, Walker VP, Dempsey PW, Kanchanapoomi M, Wheelwright M, Vazirnia A, Zhang X, Steinmeyer A, Zügel U, Hollis BW, Cheng G, Modlin RL: Convergence of IL-1beta and VDR activation pathways in human TLR2/1-induced antimicrobial responses. PLoS One 2009;4:e5810.

-43 Liu PT, Stenger S, Tang DH, Modlin RL: Cutting edge: vitamin D-mediated human antimicrobial activity against Mycobacterium tuberculosis is dependent on the induction of cathelicidin. J Immunol 2007;179:2060-2063.

44 Liu PT, Stenger S, Li H, Wenzel L, Tan BH, Krutzik SR, Ochoa MT, Schauber J, Wu K, Meinken C, Kamen DL, Wagner M, Bals R, Steinmeyer A, Zügel U, Gallo RL, Eisenberg D, Hewison M, Hollis BW, Adams IS, Bloom BR, Modlin RL: Toll-like receptor triggering of a vitamin D-mediated human antimicrobial response. Science 2006;311:1770-1773.

45 Urashima M, Segawa T, Okazaki M, Kurihara M, Wada Y, Ida H: Randomized trial of vitamin $\mathrm{D}$ supplementation to prevent seasonal influenza A in schoolchildren. Am J Clin Nutr 2010;91:1255-1260.

46 Barlow PG, Svoboda P, Mackellar A, Nash AA, York IA, Pohl J, Davidson DJ, Donis RO: Antiviral activity and increased host defense against influenza infection elicited by the human cathelicidin LL-37. PLoS One 2011; 6:e25333.

47 Doss M, White MR, Tecle T, Gantz D, Crouch EC, Jung G, Ruchala P, Waring AJ, Lehrer RI, Hartshorn KL: Interactions of alpha-, beta-, and theta-defensins with influenza A virus and surfactant protein D. J Immunol 2009; 182:7878-7887.

48 Martineau AR, Wilkinson KA, Newton SM, Floto RA, Norman AW, Skolimowska K, Davidson RN, Sorensen OE, Kampmann B, Griffiths CJ, Wilkinson RJ: IFN-gamma and TNF-independent vitamin D-inducible human suppression of mycobacteria: the role of cathelicidin LL-37. J Immunol 2007;178: 7190-7198.
Host Immune Genes and Severity of Pandemic H1N1 Influenza
Public Health Genomics 2013;16:9-16 
49 Larcombe LA, Orr PH, Lodge AM, Brown JS, Dembinski IJ, Milligan LC, Larcombe EA, Martin BD, Nickerson PW: Functional gene polymorphisms in Canadian Aboriginal populations with high rates of tuberculosis. J Infect Dis 2008;198:1175-1179.

-50 Horby P, Nguyen NY, Dunstan SJ, Baillie JK: The role of host genetics in susceptibility to influenza: a systematic review. PLoS One 2012; 7:e33180.

- 51 Bermejo-Martin JF, Ortiz de Lejarazu R, Pumarola T, Rello J, Almansa R, Ramírez P, Martin-Loeches I, Varillas D, Gallegos MC, Serón C, Micheloud D, Gomez JM, Tenorio-
Abreu A, Ramos MJ, Molina ML, Huidobro S, Sanchez E, Gordón M, Fernández V, Del Castillo A, Marcos MA, Villanueva B, López CJ, Rodríguez-Domínguez M, Galan JC, Cantón R, Lietor A, Rojo S, Eiros JM, Hinojosa C: Th1 and Th17 hypercytokinemia as early host response signature in severe pandemic influenza. Crit Care 2009;13:R201.

52 Allen IC, Scull MA, Moore CB, Holl EK, McElvania-TeKippe E, Taxman DJ, Guthrie EH, Pickles RJ, Ting JP: The NLRP3 inflammasome mediates in vivo innate immunity to influenza A virus through recognition of viral RNA Immunity 2009;30:556-565.
53 Thomas PG, Dash P, Aldridge JR Jr, Ellebedy AH, Reynolds C, Funk AJ, Martin WJ, Lamkanfi M, Webby RJ, Boyd KL, Doherty PC, Kanneganti TD: The intracellular sensor NLRP3 mediates key innate and healing responses to influenza $A$ virus via the regulation of caspase-1. Immunity 2009;30:566-575.

54 Allen IC, Moore CB, Schneider M, Lei Y, Davis $\mathrm{BK}$, Scull MA, Gris D, Roney KE, Zimmermann AG, Bowzard JB, Ranjan P, Monroe KM, Pickles RJ, Sambhara S, Ting JP: NLRX1 protein attenuates inflammatory responses to infection by interfering with the RIG-I-MAVS and TRAF6-NF- $\kappa B$ signaling pathways. Immunity 2011;34:854-865. 